University of South Carolina

Scholar Commons

\title{
Zouave Stories: Gender, Catholic Spirituality, and French Responses to the Roman Question
}

Carol E. Harrison

University of South Carolina - Columbia, ceharris@mailbox.sc.edu

Follow this and additional works at: https://scholarcommons.sc.edu/hist_facpub

Part of the History Commons

\section{Publication Info}

Published in The Journal of Modern History, ed. John W. Boyer, Jan E. Goldstein, Volume 79, Issue 2, 2007, pages 274-305.

Harrison, C. E. (2007). Zouave stories: Gender, Catholic spirituality, and French responses to the Roman question. The Journal of Modern History, 79(2), 274-305.

(C) The Journal of Modern History, 2007, University of Chicago Press

This Article is brought to you by the History, Department of at Scholar Commons. It has been accepted for inclusion in Faculty Publications by an authorized administrator of Scholar Commons. For more information, please contact digres@mailbox.sc.edu. 


\title{
Zouave Stories: Gender, Catholic Spirituality, and French Responses to the Roman Question*
}

\author{
Carol E. Harrison \\ University of South Carolina
}

In 1860, Joseph-Louis Guérin, a seminarian in the French city of Nantes, promised his mother that he would bring her a rosary blessed by Pope Pius IX. At first, she thought he was referring to the distant future, after his ordination. But he told her gently that he would be leaving for Rome immediately, and as she wept, he departed to join the pontifical Zouaves, the international volunteer force of devout Catholics dedicated to preserving the temporal sovereignty of the Holy See against the forces of the Italian Risorgimento. Guérin was wounded at the battle of Castelfidardo later that year, and he died on All Saints' Day, "in ecstasy," smiling, and with his eyes wide open and insensitive to light. In death his face "preserved the angelic form it had had in life." Guérin's story continues in a more unusual vein after his death. In March 1861, a young, desperately ill Italian girl, paralyzed, blind, and epileptic, saw a man in a peculiar uniform - baggy Arab-style trousers and a short jacket decorated with red braid - who instructed her to continue praying. The next night he appeared again and told her that her prayers had been answered: she immediately stood up, opened her eyes and saw an image of the Virgin on the wall. On her way from confession the next day, she recognized her visitor's distinctive uniform when she passed a contingent of Zouaves in the street, and, shown a photograph of the dead Guérin, she recognized him as her visitor. ${ }^{1}$ The story of Guérin's miracle circulated in Zouave commemorative literature, and for many his presumed sanctity came to represent the martyrdom of all Zouaves.

Guérin's story is evidence of a particular strain of French Catholic devotion to Pius IX and of Catholic mobilization in the face of the threat to papal sovereignty. It is a strange narrative, however, that disrupts many of our assumptions about how French men and women experienced emotion, faith, and the supernatural. This essay explores the stories told about Joseph Guérin and other Zouaves, with particular attention to what they tell us about gender and Catholic spirituality. Guérin and his fellow Zouaves were hardly typical of

* Research for this essay was supported by a summer stipend from the National Endowment for the Humanities. I am indebted to Philippe Boutry, Sarah Curtis, J. P. Daughton, the Stanford Modern France seminar, Larry Glickman, Maria LaMonaca, Jim McMillan, Father Philippe Ploix, Rebecca Stern, and the anonymous readers of the $J M H$ for their advice and assistance.

${ }^{1}$ Jules Delmas, La Neuvième Croisade, 2nd ed. (Paris, 1881), 28-29, 228-32, 247 48, 252, 291-92.

The Journal of Modern History 79 (June 2007): 274-305

(C) 2007 by The University of Chicago. 0022-2801/2007/7902-0002\$10.00

All rights reserved. 
French Catholic reaction to the Roman Question; no more than three thousand Frenchmen served with the pontifical Zouaves. These volunteers fell at one extreme of a possible range of responses to an issue that divided Catholics and perplexed the French state. Nonetheless, Zouave stories appealed to a large number of French Catholics, male and female, who were attracted by Zouaves' valorization of suffering and their explicit yearning for martyrdom.

Zouave stories positioned their heroes as the fulcrum of an intensely personal relationship with Rome and with the pope that many devout French Catholics embraced. Guérin's story sets out the three crucial components of these Zouave narratives. First is the Zouave hero himself, a figure who, to the modern reader, seems characterized by gender ambiguity because he fits so poorly into existing scholarly narratives based on bourgeois family life, separate spheres, and a feminized church. Second is the Zouave's mother: although she plays a marginal role in the military setting, her suffering invites other women, and, more generally, other Catholics, to engage in the Roman drama. Finally, the question of sainthood emphasizes the extent to which devout Catholics imagined the Roman Question as having a supernatural dimension: Zouave sacrifice in Italy transformed these young men into intercessors in heaven as well as in Rome.

\section{The Roman Question and the Zouave Response}

The temporal sovereignty of the papacy was a question of fundamental importance for Italian nationalists and Catholics worldwide in the 1850s and 1860s; the French church and the French state were deeply entangled in the issue. Although the election of the liberally inclined Giovanni Maria MastaiFerretti as Pope Pius IX in 1846 raised hopes for an Italy united behind the papacy, the experience of 1848 and Pius's seven-month exile during the Roman Republic made the Holy See an intractable obstacle to the project of Italian unity. Pius IX remained intransigently opposed to negotiations with the ambitious Piedmontese state, and the famous 1864 Syllabus of Errors stated clearly the papacy's opposition to liberalism, nationalism, and the modern, secular state. Papal popularity developed alongside papal intransigence, and a cult of papal devotion emerged around the figure of the suffering pontiff. Although it was increasingly clear that there were no grounds for compromise between Pius IX and Italian nationalists, the French Second Empire persistently attempted to broker a solution to the Roman Question that would include both an Italian nation-state and a sovereign pope. ${ }^{2}$

\footnotetext{
${ }^{2}$ For an account of the events of the Risorgimento from a Roman point of view, see Henri Daniel-Rops, The Church in an Age of Revolution, 1789-1870, trans. John Warrington (New York, 1965), chap. 5. On Catholic responses to the Roman Question
} 
Pius IX returned to Rome from his exile in April 1850 alongside a small French military force sent to the Papal States. Louis Napoleon Bonaparte, anxious to consolidate his conservative credentials with French Catholics, deployed this support for papal sovereignty to counter his own background as a youthful participant in revolutionary Italian politics. This restoration of papal sovereignty inaugurated France's complex and frustrating involvement in the Roman Question. Napoleon III found himself locked into military support of papal territory, unable either to lose face by pulling out or to force liberal reforms on the papal government. ${ }^{3}$ Military presence gave the French no leverage over the Holy See. French disapproval did nothing to return Edgardo Mortara, the Roman Jewish boy secretly baptized by a Christian servant and kidnapped by Pius's government, to his family. Nor could French diplomacy moderate the Syllabus of Errors or encourage secular reforms in Roman government.

Catholic mobilization, in France and elsewhere, began in earnest in response to the Italian War of 1859, as Piedmont, with French support, invaded Austrian territories in northern Italy. After French withdrawal from the conflict and in response to the growing popularity of Garibaldi in the south, the Piedmontese invaded the Papal States. In September 1860, the newly organized papal volunteers and Piedmontese forces met at the battle of Castelfidardo, the Piedmontese victory in which Joseph Guérin died, and Piedmont prepared to annex large sections of papal land in central Italy. Napoleon III, although prepared to accept greatly diminished papal territory, drew the line at the complete elimination of papal sovereignty and declared that French troops would defend the papacy. A nominal French force then protected the frontiers of papal territory, now reduced to the traditional patrimony of Saint Peter surrounding the city of Rome. This rump papal state satisfied hardly anyone: neither Italian nationalists nor devout Catholics accepted the situation in 1860 as legitimate. Napoleon III, practically the only person who approved of the status quo, found himself committed to maintaining it with a French military presence.

Engagement in Italy remained a problem for the duration of the Second Empire. The September Convention of 1864 was supposed to extricate Napoleon III: France agreed to remove troops from Rome within two years in return for a promise from Piedmont (now the kingdom of Italy) not to attack papal territory. Just as French troops withdrew, however, Garibaldi began gathering volunteers to attack papal Rome, and Napoleon found himself obliged

outside of France, see Emiel Lamberts, ed., The Black International-L'Internationale noire, 1870-1878: The Holy See and Militant Catholicism in Europe (Leuven, 2002); and Peter d'Agostino, Rome in America: Transnational Catholicism from the Risorgimento to Fascism (Chapel Hill, NC, 2004).

${ }^{3}$ Jean Maurain, Un Bourgeois français au XIXe siècle: Baroche, ministre de Napoléon III, d'après ses papiers inédits (Paris, 1936), 181-94, 234-40, 389-94. 
to send the French force back. French and papal troops together defeated the Garibaldini at the battle of Mentana in November 1867. Ultimately, the FrancoPrussian War and the fall of the Second Empire resolved both the impasse of the French presence in Rome and the question of papal territory. Faced with a German war, Napoleon III ordered French troops back from Rome at the end of July 1870. A few weeks after French defeat at Sedan, Rome surrendered to Italian forces following a purely symbolic resistance at the Porta Pia in late September. Pius IX retreated to his palace where, in the role of "prisoner of the Vatican," he remained a powerful symbol of the clash between Catholics and the new Italian state and, by extension, between the devout and modern nation-states.

The Roman Question produced no simple dichotomies of opinion: it divided French policy makers, the papal bureaucracy, and French Catholics. Napoleon III's course of action reflected attempts to conciliate disputes among his inner circle between supporters of the pope on the one hand and the Italianissimes on the other. Vatican officials debated among themselves whether or not the pope was best served by a policy that relied on the French presence or by the expansion of the pope's own forces. ${ }^{4}$ The Roman Question also exacerbated the divisions within the French episcopacy: Bruno Horaist notes that it was not until the 1860s that French bishops' support for temporal sovereignty solidified. ${ }^{5}$ Even so, Gallican bishops - those committed to the autonomy of the French church - and their ultramontane counterparts, who supported a more centralized and Roman organization of authority, disagreed over appropriate manifestations of support for the pope's territorial claims. ${ }^{6}$ While some bishops enthusiastically promoted Zouave recruitment and other programs to support the Papal States such as the parish collections known as Peter's Pence or the purchase of papal bonds, others were decidedly lukewarm. Gallican bishops, in particular, recognized a clear link between the mobilization of lower clergy and their parishioners around the Roman Question and the debates over papal infallibility, proclaimed in spite of significant minority objections at the Vatican Council in 1869.

Zouave recruitment reflected these disputes. Within the Vatican, there were

\footnotetext{
${ }^{4}$ Frank J. Coppa, Cardinal Giacomo Antonelli and Papal Politics in European Affairs (Albany, NY, 1990), 119-25; and Roger Aubert, "L'Eglise face au problème de Rome," in La fine del potere temporale e il ricogiungimento di Roma all'Italia, ed. Congresso di storia del Risorgimento italiano (Rome, 1972), 5-38.

${ }_{5}^{5}$ Bruno Horaist, La Dévotion au pape et les catholiques français sous le pontificat de Pie IX (1846-1878) d'après les archives de la Bibliothèque apostolique vaticane (Rome, 1995), 24.

${ }^{6}$ Austin Gough, Paris and Rome: The Gallican Church and the Ultramontane Campaign, 1848-1853 (Oxford, 1986), 233-36. See also Jacques Gadille, La Pensée et l'action politiques des évêques français au début de la IIIe République (1870-1883) (Paris, 1967), vol. 1.
} 
fundamental disagreements between Monsignor de Mérode, the pope's minister of war, who believed that the Zouaves should be a real military force capable of defending papal territory, and the secretary of state, Cardinal Antonelli, who saw the Zouaves as symbolic of international Catholic support for the papacy but who relied on French backing to protect temporal sovereignty. ${ }^{7}$ The French state was inconsistent, keeping a small occupation force in Rome but threatening Frenchmen who volunteered for the papal army with loss of citizenship. After the September Convention, the Second Empire allowed papal agents to recruit in France for a Roman legion but made it difficult and expensive to join. ${ }^{8}$ Finally, French bishops' enthusiasm for the Zouaves and other manifestations of support for the papacy varied greatly. In some dioceses, bishops not only encouraged young men to join up but also promoted Zouave committees that raised money to equip and send volunteers to Rome. Enthusiastic clerical support on the parish level was key to recruitment patterns. Although every French department sent at least one Zouave, a single commune in the Breton diocese of Nantes produced twenty-nine volunteers; the southern department of the Gard, thanks to the tireless work of Emmanuel d'Alzon and the Assumptionist fathers, likewise offered more than its share. Distribution of Zouave recruitment thus reflected a particular kind of Catholic loyalty: intransigent, ultramontane, and often driven by lower clergy. ${ }^{9}$

Thanks to these disputes at all levels of the Roman Question, a devout and enthusiastic young Frenchman might or might not find a parish priest or a schoolmaster to encourage his vague notions of becoming a Zouave. If he were not independently wealthy, he might or might not find that his bishop had organized a Catholic Committee that would fund his equipment and his travel.

\footnotetext{
${ }^{7}$ Roger Aubert, "La Chute de Monseigneur de Mérode en 1865," Revista di storia della chiesa in Italia 9 (1955): 331-92.

${ }^{8}$ Jean Guenel, La Dernière Guerre du Pape: Les zouaves pontificaux au secours du Saint-Siège, 1860-1870 (Rennes, 1998), 88-89. The Roman legion (known as the Légion d'Antibes in France) never caught the public imagination as the Zouaves did.

${ }^{9}$ See Guenel, La Dernière Guerre, 41, for the geographic distribution of French recruitment; and, on the Gard, "Appel aux curés des diocèses voisins de Nimes," in Lettres du P Emmanuel d'Alzon, vol. 7, 1868-1869 (Rome, 1994), 2-3. The significant presence of Bretons - particularly of legitimist sons of the Vendée like the Charette brothers - quickly became part of the Zouave myth. Patrick Nouaille-Degorce, "Zouaves pontificaux et volontaires de l'ouest dans la guerre de 1870-1871: Présentation des Matricules régimentaires" (Mémoire de DEA, Université de Nantes, 2000), questions the mythology of Zouaves as latter-day Chouans. He notes that recruitment did not precisely follow the boundaries of the Vendée, that noblemen were never more than 10 percent of Zouaves, and that volunteers often came in clusters from a single village or Catholic school, frequently signing up on the same day $(31-32,45-47,55)$. Finally, recruitment for the Roman legion followed a completely different pattern, drawing largely from Alsace and the Franche Comté because of the presence of recruiting offices in Altkirch and Pontarlier (Guenel, La Dernière Guerre, 89).
} 
If he wrote to the papal nuncio, he would probably receive the formulaic discouraging response that the nuncio did not concern himself with Zouave recruitment. ${ }^{10}$ Even without centralized organization and the unified support of the church hierarchy, however, the Zouaves' strength grew from a few hundred in the early 1860 s to over three thousand by $1870 .{ }^{11}$

Absence of centralization and clerical consensus also did not prevent the pontifical Zouaves from capturing the public imagination. The figure of the Zouave was the hinge that connected the pope to many of his French children in a deeply personal way: in the narratives of Roman service disseminated among French Catholics, the Zouave linked his loved ones at home, especially his womenfolk, to the beleaguered Pius IX. ${ }^{12}$ French audiences had many sources of Zouave stories to choose from. They could follow their Zouave heroes in the meetings of Catholic Committees and in the pages of the ultramontane newspaper Univers or of their local papers, which tracked the donations that clothed and equipped the Zouaves. ${ }^{13}$ In the late 1860 s, readers of the Petit Echo de Rome, Journal du Concile, could follow its rubric "Chronique des zouaves." Several Zouaves published descriptions of their time in Italy, and family and friends regularly eulogized dead Zouaves in biographical accounts of their sacrifice. Letters from young men in Rome seem to have circulated among devout Catholics, and they formed the basis of collective biographies of Zouave dead. Finally, Zouaves also appeared as fictional heroes of Catholic novels. ${ }^{14}$

${ }^{10}$ See the letters in Archivio Segreto Vaticano, Arch. Nunz. Parigi, Nunz. Saccioni (1853-61) 8, Truppe estere nello Stato Pontificio-for instance folio 126 (April 27, 1859), which directs the Vicomte de Faly to make his enquiries with the Ministry of War in Rome.

${ }^{11}$ Guenel, La Dernière Guerre, 39-40. By 1870, the roughly three thousand Zouaves constituted 22 percent of the papal forces (Philippe Boutry, "Zouaves, pontifical," in The Papacy: An Encyclopedia, 3 vols., ed. Philippe Levillain [New York, 2002], 3:1643). Before the battle of Castelfidardo (1860), the foreign volunteers were generally known in the French literature as the "tirailleurs franco-belges," and the Zouave uniform that the officers wore had not been universally adopted. After Castelfidardo, the uniform and the "zouaves pontificaux" name were commonly used. For convenience, I use "Zouave" throughout this essay to refer to this international Catholic movement (Guenel, La Dernière Guerre, 39; Nouaille-Degorce, "Zouaves pontificaux," 30).

${ }^{12}$ See Horaist, La Dévotion, 56, on Zouaves as intermediaries for their families.

${ }^{13}$ The Univers's importance in keeping the Roman Question in the forefront of Catholic minds was enormous, although it was suppressed from 1860 to 1867, in large measure because of its noisy ultramontanism. As several scholars have noted, the Univers's influence extended well beyond its relatively limited press runs (around eleven thousand for the most sensational issues) because it was so widely read among the lower clergy. See Gough, Paris and Rome, 223.

${ }^{14}$ Because the Zouave story changed significantly in 1870 after the fall of Rome when French Zouaves returned home and became the kernel of the regiment of the 
These Zouave stories - journalistic, biographical, and fictional — follow common and repetitive narrative patterns. They create the impression of intimacy, relying heavily on private correspondence and on the testimony of griefstricken mothers. Some accounts of Zouaves were indeed intimate creations, privately printed and circulated among family and friends. Stories of individual Zouaves were recycled from one account to another, so that private family stories found their way to a larger Catholic readership in martyrologies of the Zouave cause, written by prominent Catholic writers such as Anatole de Ségur. ${ }^{15}$ Ultimately, the Zouave narrative reached a mass Catholic audience in the periodical press, either in the pages of diocesan Semaines religieuses or in the national Univers. ${ }^{16}$ The crucial elements of the Zouave story remained consistent: loyalty to a hopeless cause and physical suffering, even death, in the name of that devotion. The bond between pope and people in these narratives was Zouave sacrifice, and the intimate tale of the individual Zouave martyr invited the reader to experience that bond in an immediate and personal fashion.

"Voluntaires de l'Ouest" in the Franco-Prussian War, I focus primarily (although not exclusively) on texts written before 1870 . Nouaille-Degorce, "Zouaves pontificaux," 7 , makes a convincing case for significantly different recruitment patterns for the Volontaires de l'Ouest, and it seems clear that the Charette brothers and their legitimist politics quickly came to dominate Zouave mythmaking. Nonetheless, many of the biographies published after 1870 draw heavily on Zouave correspondence from the Italian years and are worth consulting in this context. For an account of the Zouaves that focuses on their role in the Franco-Prussian War and the politics of the Third Republic, see Raymond Jonas, France and the Cult of the Sacred Heart: An Epic Tale for Modern Times (Berkeley, 2000). The Risorgimento produced its own martyrologies, e.g., Mentana: Cenni storici sulla campagna del 1867 per l'indipendenza d'Italia e libertà di Roma (Milan, 1874); and Felice Venosta, Roma e i suoi Martiri (Milan, 1867).

${ }^{15}$ Zouave stories were a significant part of the heyday of Catholic publishing under the Second Empire, and particularly of its dramatic spike around 1861-62 that Claude Savart has documented (Les Catholiques en France au XIXe siècle: Le témoignage du livre religieux [Paris, 1985], 108-9, 194, 494, 713). In these key years following Castelfidardo, just over 20 percent of the total number of titles published in France were "Catholic." In 1861, the year Savart analyzes in detail, the "Roman Question" produced more titles than any other theme in the categories "spirituality" and "theology": seventy-two out of 2,032 Catholic titles produced that year. In 1861 as always, devotional manuals and lives of saints were the main areas of production.

${ }^{16}$ Horaist, La Dévotion, 59, measures the impact of the Roman question by examining letters from France to Pius IX; he estimates that 2 percent of the French population made some formal expression of support directly to the pope in 1864 and again in 1870 , a figure that rose to 6.5 percent in 1871 . Pius IX was not, of course, the only person to whom French Catholics could express their opinions, so these figures only hint at the total numbers of those who followed the Roman drama. It is also worth noting that of the 95 million francs donated to Peter's Pence collections from 1859 to 1870, fully 40 percent came from France, mostly as small gifts (Lamberts, The Black International, 145-46; John F. Pollard, Money and the Rise of the Modern Papacy: Financing the Vatican, 1850-1950 [New York, 2005], 33-35). 
Zouave stories clearly fall into the tradition of a dolorist Catholicism that celebrates suffering, agony, and defeat as triumphant steps toward the expiation of $\sin .{ }^{17}$ It is easy to read Zouave narratives as what William Reddy has recently called "emotives" - statements that describe emotional conditions while simultaneously cultivating and shaping the feelings in question. ${ }^{18}$ The ritual invocation and repetition of the young man's spiritual and physical pain across Zouave texts were clearly more than a simple reflection of objectively existing sentiment. Rather, these stories created a template for the Zouave experience, a vocabulary that not only served the young men in uniform but also informed the grief and devotion of many French Catholics. The Zouave story schooled French Catholics in their response to the Roman Question; it taught readers how they might participate in the suffering of the pope and the church, and it reassured them that such suffering was, indeed, redemptive. The Zouave narrative rallied French Catholics to the view that the Risorgimento challenged God's will for his human creatures, not merely the diplomats' territorial arrangement of Restoration Italy.

Zouave narratives explicitly made this emotional template available to women as well as to men: although the heroes were always young men, the expression of grief at Catholic defeat was incomplete without female suffering. It is important to examine male and female identity in the Zouave story in the contexts of ultramontane Catholicism and nineteenth-century French culture, recognizing, however, that these contexts do not represent "two Frances." ${ }^{19}$ The Zouave experience does not fit easily into scholarly accounts of a feminized Catholicism or of a bourgeois order based in secular, male rationality and emotional restraint. In this literature, there is division of spiritual labor but no feminization of religion..$^{20}$ There are bourgeois families, but there are no separate

\footnotetext{
${ }^{17}$ For recent historical explorations of this tradition, see Richard D. E. Burton, Holy Tears, Holy Blood: Women, Catholicism, and the Culture of Suffering in France, 18401870 (Ithaca, NY, 2004); and Ruth Harris, Lourdes: Body and Spirit in the Secular Age (New York, 1999).

${ }^{18}$ William M. Reddy, The Navigation of Feeling: A Framework for the History of the Emotions (New York, 2001), 104-5.

${ }^{19}$ Claude Langlois, "Catholics and Seculars," in Realms of Memory: Rethinking the French Past, vol. 1, Conflicts and Divisions, ed. Pierre Nora and trans. Arthur Goldhammer (New York, 1996), 109-43.

${ }^{20}$ Claude Langlois, who has contributed as much to the dissemination of a concept of a "feminization of religion" as anyone else, recently noted that the phrase "has spread to the point of becoming a linguistic tic" ("Le Catholicisme au féminin revisité," in Femmes dans la cité, 1815-1871, ed. Alain Corbin et al. [Paris, 1997], 139-49, 141). See also his "Toujours plus pratiquantes: La permanence du dimorphisme sexuel dans le catholicisme français," Clio 2 (1995), http://clio.revues.org; and Le Catholicisme au féminin: Les Congrégations françaises à supérieure générale au XIXe siècle (Paris, 1984). The concept is central to women's history: see Michael P. Carroll, "Give Me That Ol' Time Hormonal Religion," Journal for the Scientific Study of Religion 43
} 


\section{Harrison}

spheres, no division between a female world of love and sentiment and a male space of autonomous reason.

The intense emotions of the Zouave story often seem quite foreign to the scholar's bourgeois nineteenth century, which, according to Reddy, was characterized by a "pessimism about the role of emotions in human life" and a desire to banish these emotions to the most private realms of experience. ${ }^{21}$ For the devout French men and women who witnessed the threat to the papacy, the idea that sentiment had no place in public affairs was itself a source of emotional anguish. Zouave literature shaped and expressed their profound distress and their conviction that the disposition of Italian territory was not merely a matter for the diplomats but a question that placed souls in jeopardy. Zouave stories were, in Reddy's terminology, an "emotional refuge." Their assertion that suffering and love were indeed relevant to the Roman Question offered the devout a "safe release from prevailing emotional norms" with which they found themselves in conflict. ${ }^{22}$ The spiritual world of the Zouaves and of the women who supported them-and who sometimes described themselves as Zouaves as well-encouraged the cultivation of profound emotion, particularly pain and grief, and it explicitly linked the private anguish of the devout Catholic with the political actions of European states.

(2004): 275-78; Lynn Abrams, The Making of Modern Woman: Europe, 1789-1918 (New York, 2002), 34-40; Michela de Giorgio, "The Catholic Model," trans. Joan Bond Sax, in A History of Women in the West, vol. 4, Emerging Feminism from Revolution to the Great War, ed. Geneviève Fraisse and Michelle Perrot (Cambridge, MA, 1993), 169-77; Olwen Hufton, "Women in Revolution," French Politics and Society 7, no. 3 (1989): 65-81; Marlène Albert-Llorca, "Les Femmes dans les apparitions mariales de l'époque contemporaine," Clio 15 (2002), http://clio.revues.org; Marina Caffiero, "Dall'esplosione mistica tardo-barocca all' apostolato sociale (1650-1850)," in Storia delle donne in Italia: Donne et fede; santità e vita religiosa in Italia, ed. Lucreta Sacraffia and Gabrielle Zarri (Rome, 1994), 327-73; Catherine Maurer, "Le Catholicism au féminin: L'expansion des congrégations dans l'Allemagne au XIXe siècle," Histoire, Economie, et Société 21 (2002): 17-28. Historians of twentiethcentury France writing about subjects such as republican anticlericalism and antifeminism also rely on the concept (Judith F. Stone, "Anticlericals and Bonnes Soeurs: The Rhetoric of the 1901 Law on Associations," French Historical Studies 23 [2001]: 10328; and Paul Smith, Feminism and the Third Republic, 1918-1945 [Oxford, 1996], 5). Historians of religion have recently challenged the notion of a feminized church (Paul Seeley, "O Sainte Mère: Liberalism and the Socialization of Catholic Men in NineteenthCentury France," Journal of Modern History 70 [1998]: 862-91; and James F. McMillan, "Religion and Gender in Modern France: Some Reflections," in Religion, Society, and Politics in France since 1789, ed. Frank Tallet and Nicholas Atkin [London, 1991], 55-66).

${ }^{21}$ Reddy, Navigation, 147.

22 Ibid., 129. 


\section{READING THE ZOUAVE}

The pontifical Zouave was not a typical male hero: fragility, gentleness, and perfect innocence characterized the protagonist of the Zouave story. The trajectory of the Zouave plot destined young men for military defeat and for lives cut short: they would remain forever their mothers' sons, never moving on to marriage and full adulthood. Zouaves cultivated physical suffering not in the expectation of victory-God, not the Zouaves, would save the Papal Statesbut for its own sake. It would be a mistake, however, to characterize the Zouaves' delicacy and fascination with bodily pain as effeminate. Rather, it is important to consider the articulation between religious faith and gender identity. Individuals seeking to participate in the intense emotional experience of the pope's martyrdom found their identities as men and as sons transformed by this commitment.

The only Zouaves who adhered to the familiar gender conventions of nineteenth-century society and fit into stereotypical marriage plots were fictional. Only in novels did the Zouave story end happily, with the creation of a new Catholic family. The first Zouave novel, by the Italian priest Antonio Bresciani, was translated into French within a year of its initial appearance in 1861, and it features a conventional romance. Le Zouave pontifical weaves an imaginary plot into the lives of real Zouaves, from whose letters Bresciani quotes extensively. The novel's fictional hero, Olderic, serves with distinction and is wounded at the battle of Castelfidardo but miraculously survives. Jacqueline, for her part, remains in Brittany and grapples with questions of faith and love: how can she desire Olderic's safety when he asks for nothing more than martyrdom? Jacqueline's suffering — physical in nature if spiritual in origin-parallels that of Olderic, who weeps not when he is shot in the head but when he hears of the saintly death of the very real Joseph Guérin. The novel ends with a wedding and the promise of a new, happy family: Olderic's wounds have miraculously healed, and Jacqueline has learned that she is a woman, not an angel, and therefore meant to seek love and not martyrdom. Bresciani coyly tells his readers that, although he has changed their names, Olderic and Jacqueline might well be real people, like the many actual Zouaves whose experiences fill most of the book. ${ }^{23}$

The best-known author to adopt a Zouave hero was the prolific writer of juvenile fiction Madame de Ségur, whose last novel, Après la pluie le beau temps, similarly features a pious heroine and her Zouave lover. The orphan

\footnotetext{
${ }^{23}$ Antonio Bresciani, Le Zouave pontifical (Paris, 1862). The Italian text, Olderico, ovvero il Zuavo pontificio, in Bresciani, Opere, vol. 15 (1861; Rome, 1868), footnotes its sources, primarily French and Belgian newspapers and private letters in the possession of Zouave families.
} 
Geneviève is the object of her uncle's devious plot to marry her to her impoverished cousin. Her other, more worthy cousin Jacques joins the Zouaves and marries Geneviève, rescuing her and taking her to Rome, where they experience together the awe-inspiring papal city. He emerges from battle victorious, having distinguished himself "with the bravery and the dash that proclaimed the Frenchman." ${ }^{24}$ Rome may fall, but the family remains intact. Jacques, like Olderic, is a fully conventional hero, and his Zouave experience is a guarantee of his future qualities as husband and father. As a former Zouave, Jacques will be free to love Geneviève and their children; his devotion to the papacy is not an all-consuming passion. At the end of the novel, Jacques belongs to Geneviève and to their future together; he is not free to represent a Catholic anguish that would allow readers to share in the sufferings of the church.

Gabriel Gerny's 1863 novella Les Soldats du pape also features a marriage plot, although the Zouave hero is slightly more ambiguous than Madame de Ségur's Jacques. The obstacle to young Berthe Lefort's happiness is her father's distaste for the Zouave Gaston de Verneuil. The young man "was a beautiful blond with a delicate, dreamy face, big, clear, blue eyes, and a sweet, childlike mouth." ${ }^{25}$ As pretty as he is, the narrator notes, it is no wonder that Berthe's father, General Lefort, an old Napoleonic soldier, failed to note Gaston's sprouting moustache and referred to him as "a wet hen, a man without energy or character, dominated by priests." ${ }^{26}$ The action shifts to Rome, where the conversion of the general and the trial of Gaston's manliness ("He left as a child, and now he is a man") take up the rest of the novel. ${ }^{27}$ By the end, hero and heroine have been molded into suitable marriage partners, but the wedding never occurs. Both men die on the field of Castelfidardo, and Berthe and her mother enter a convent a fortnight later.

Gerny's novella, with its refusal of a marriage in favor of a less conventionally "happy" ending - conversion, martyrdom, and vocation-more closely resembles true Zouave stories, with their focus on sacrifice rather than individual fulfillment. Catholic novels, however morally upright they might be, remained novels, both subject to the demands of the genre and excluded from the ranks of properly devotional literature. Marriage remained the key ingredient of the fictional plot. Zouave biography, however, had greater freedom than the novel to model itself on hagiographic and devotional texts, and its heroes aspired to sanctity rather than to marriage. For the characters of most real Zouave nar-

${ }^{24}$ Sophie de Ségur, Après la pluie le beau temps (1871; Paris, 1991), 335. See also Comte de Saint-Jean [Mme Eugène Adine Broband], Mobiles et Zouaves Bretons (Nantes, 1871), also a marriage novel with a Zouave hero, although focusing on the Franco-Prussian War.

${ }^{25}$ Gabriel Gerny, Les Soldats du pape: Un dévouement filial (Paris, 1863), 26.

${ }^{26}$ Ibid., 24.

${ }^{27}$ Ibid., 53. 
ratives, as for Gaston and the Leforts, a desire to participate in the church's passion overrides all earthly attachments.

Any number of real Zouaves could have been the model for the fictional Gaston de Verneuil, with his rosy cheeks and wide innocent eyes. Gaston, more than Olderic or Jacques, captures the fascination with courage housed in delicate bodies that characterized Zouave biography. ${ }^{28}$ Accounts of Zouaves, often published as memorials by their families, regularly introduce their heroes in comparable terms. The stories of actual Zouaves, however, do not even contemplate resolving themselves into marriages: their dead heroes remain sons, lost to their loving families, especially their mothers. To look at Mizael le Mesre de Pas, "you would practically have thought he was a girl, so virginal and modest was his appearance." ${ }^{29}$ His sister tried to talk Mizael out of joining the Zouaves because he was physically weak and not the type to make a good soldier: he responded that the pope needed "devoted hearts" above all and volunteered anyway. Xavier Bouquet des Chaux had walked on crutches as a child but fully accepted the discipline of military life despite his uncertain health. ${ }^{30}$ Etienne Melin insisted on volunteering despite his illness: he would do paperwork if he were too ill to fight. ${ }^{31}$ The Zouaves initially refused a seventeen-year-old boy who traveled to Rome to volunteer as an expression of gratitude for his father's conversion, but his ardor was such that the officers relented and allowed him to enlist. ${ }^{32}$ In all of these cases, the reader knows from the very beginning that these are lambs sent to the slaughter, not effective soldiers, and that the mission of the pope's army is martyrdom, not murder.

The Zouaves were eager to experience what Monseigneur Dupanloup, Bishop of Orléans, described in a Zouave eulogy as the "painful mystery of war." 33 The "mystery" of warfare in the papal territories lay in the Zouaves' antici-

\footnotetext{
${ }^{28}$ The apparent confusion about Olderic's age in the first pages of Le Zouave pontifical suggests that Bresciani was well aware of this stereotype. Although Olderic is barely older than Jacqueline, who celebrates her seventeenth birthday in the first chapter, Bresciani notes especially his "collar of dark beard" (6).

${ }^{29}$ Anatole de Ségur, Les Martyrs de Castelfidardo (Paris, 1861), 74. See also Delmas, Neuvième Croisade, 86.

${ }^{30}$ [R. de Saint-Gérand], Vie de Xavier Bouquet des Chaux, Capitaine aux Zouaves pontificaux, volontaire de l'ouest en 1870-1871 (Lyon, 1901), 20-21, 42-43.

${ }^{31}$ Delmas, Neuvième Croisade, 380; and Saint-Gérand, Vie de Xavier Bouquet des Chaux, 70-71.

${ }^{32}$ Delmas, Neuvième Croisade, 375-76. The elderly also make a few appearances in the Zouave literature: the duc de Lorges patrolled the streets of Rome because he was too old for regular service, and the Baron de Crozes went to Rome to serve at age eighty-four; the author does not tell us what the Zouaves found for him to do (ibid., 384).

${ }^{33}$ Oraison funèbre du Général de la Moricière, prononcée dans la cathédrale de
} Nantes, le mardi 17 octobre 1865 par Mgr l'Evêque d'Orléans (Paris, 1865), 6. 
pation of victory to be achieved through military defeat and individual suffering. The glorification of defeat is a common theme in Zouave narratives, particularly in accounts of General de la Moricière, who led papal troops into the battle of Castelfidardo. The general was a French military hero, responsible for the French conquest of North Africa. Having served as minister of war under the Second Republic, La Moricière refused to compromise with LouisNapoleon and was living in exile in Belgium when he volunteered to serve the pope. La Moricière's own accounts of the battle were dry and official, but other writers dwelt upon the ironic contrast between the general's military victories and his greater spiritual victory, which emerged from the defeat at Castelfidardo. ${ }^{34}$ Louis-Aimé de Becdelièvre, for instance, recalled General de la Moricière's speech to his troops on the eve of battle: the general encouraged his men to sacrifice their lives in a "bloody protest" and announced that "victory is not our goal." Colonel de Becdelièvre reinforced his general's message of glorious defeat by reminding his men that they should prepare themselves to meet God, in whose army they fought, and he encouraged them all to confess before battle. ${ }^{35}$ Eulogies for the general, who died in 1865, emphasized that like the volunteers who served under his command, he was "God's vanquished": having lost everything, La Moricière heard the voice of Christ offering to be "[his] patrie, [his] home, [his] land, and [his] peace!" 36

The appeal of defeat and the sense of temporal sovereignty as a lost cause resonated in other Zouave narratives. Oscar de Poli, who published several books on the Zouaves, identified himself as "one of the vanquished of Castelfidardo." ${ }^{37}$ Henri de Verthamon explained to his family that he offered himself knowing that "obviously by ourselves we can neither recover what the Pope has lost, nor perhaps even retain what has so far escaped the shipwreck, but we can protest, by our deeds and in front of everyone." ${ }^{38}$ Alfred de la Barre de Nanteuil had a presentiment of his own death but wrote that he would "carry

${ }^{34}$ Rapport du Général de la Moricière à Monseigneur de Mérode . . . sur les opérations de l'armée pontificale (Paris, 1860); Mariage de M le comte François de Maistre, capitaine d'état-major dans l'armée pontificale avec Mlle Henriette de la Moricière (n.p., n.d.), 10.

${ }^{35}$ Louis-Aimé de Becdelièvre, Souvenirs de l'armée pontificale (Paris, 1867), 67$68,72$.

${ }^{36}$ Oraison funèbre, 23, 43, 44. See also Eugène de la Gournerie, Notes biographiques sur le Général de la Moricière (Nantes, 1865). By way of contrast, Frank RussellKillough, Dix Années au service pontifical, récits et souvenirs (Paris, 1871), is remarkable for its cheerful account of the papal army and includes comic anecdotes about La Moricière's occasionally poor judgment, his temper, and his swearing ("the full African vocabulary, which hadn't yet been purified by the atmosphere of Christian Rome"), chap. 4.

${ }^{37}$ Oscar de Poli, Les Soldats du pape (1860-1867) (Paris, 1868), 1.

${ }^{38}$ Henri de Verthamon, zouave pontifical, volontaire de l'ouest (Perigeux, 1873), 52. 
into the grave the consoling thought that our cadavers ... will become the pedestal on which right is reestablished." ${ }^{39}$ Adéodat Dufournel addressed God in his diary in 1867, expressing his frustration with the years of inaction following Castelfidardo, during which the threat to the pope receded: "Jacob served Laban for seven years to obtain Rachel. It is seven years now, Lord, that I have served your Vicar: will you finally give me that good death on the battlefield to which I aspire!"40 Adéodat's wish was granted; the situation in Rome deteriorated, and both he and his brother Emmanuel died in the futile defense of Rome. ${ }^{41}$

Zouave chaplains fully approved of their flock's desire for a martyr's death, and they agreed that defeat added to the grandeur of the cause. The Jesuit Eugène de Gerlache noted in his account of the fall of Rome that his story was about sacrifice rather than victory, "but is voluntary sacrifice not the most noble of victories?"'2 Jules Daniel, another chaplain, strenuously rejected the notion that practical military victory should be the goal of the Zouaves; in a letter to Monseigneur Richard, Vicar General in Nantes, he maintained that "we need victims, who will be all the more acceptable to God insofar as they are volunteers." ${ }^{43}$ The abbé Peigné, having heard confessions before the battle of Mentana, reported that many of these "children of faith" desired martyrdom on the battlefield: it was "easier to die as a soldier of the Church than to live constantly as a good Christian!" ${ }^{44}$ Laymen and priests agreed that sacrifice, even of life, was valuable for its own sake, regardless of its effect on the political situation in Italy.

Key to Zouaves' martyrdom was their sexual purity, and Zouave narratives often emphasized the tension between barracks life and personal holiness: readers were fascinated with the idea of the chaste Christian crusader. The Zouave Pinsonneau, who joined up with his fellow seminarian Joseph Guérin, wrote that he had entered "a new Seminary, less ecclesiastical, ... but with nearly as much piety and as many virtues.... I guarantee, to preserve an ecclesiastical vocation, there is nowhere better than among us." ${ }^{45}$ Guérin, like

${ }^{39}$ Delmas, Neuvième Croisade, 31.

${ }^{40}$ Quoted in H. Derély, Vingt-Quatre Heures aux avant postes (Lille and Paris, n.d.), 47-48.

${ }^{41}$ Ibid., 48-59; J.-S. Allard, Les Zouaves pontificaux, ou journal de Mgr Daniel, aumonier des zouaves, camérier secret de SS Pie IX et de SS Léon XIII (Nantes, 1880), 310, 325, 339.

${ }^{42}$ Eugène de Gerlache, Les Derniers Jours de l'armée pontificale (Tours, 1870), 5.

${ }^{43}$ Archives Historiques de l'Archevêché de Paris (hereafter AHAP), I DX7 (papiers Richard), n.d., folder A, letter B.

${ }^{44}$ AHAP, I DX7, November 10, 1867, folder A, letter 27.

${ }^{45}$ Quoted in J.-S. Allard, Le Volontaire Joseph-Louis Guérin du corps des zouaves pontificaux (Nantes, 1860), 33. Fascination with the moral purity of the pontifical Zou- 
many Zouaves, acknowledged that military life was "full of snares and precipices," but he reassured his family that he was careful to preserve his "Christian and ecclesiastical habits," especially weekly communion. ${ }^{46}$ Guérin was well known for discouraging rough behavior among his colleagues, chiding the boisterous for borrowing their manners from the Garibaldini. ${ }^{47}$ The abbé Daniel acknowledged that not all Zouaves lived up to Guérin's standard but generally described their behavior as "angelic." ${ }^{48} \mathrm{He}$ also believed, however, that the Piedmontese were pursuing "an infernal crusade against Zouave virtue" by sending prostitutes into their garrisons; fortunately, he said, the Zouaves denounced these women and had them sent to jail. ${ }^{49}$

Mothers also expressed concern for their sons' moral peril and rejoiced in their purity. The mother of a dead Zouave wrote of her gratitude that God "[kept] and bless[ed] [her] son's youth, using it in such a saintly and noble fashion," and another thanked God for taking her son "to preserve him from dangers that he had yet to encounter and to receive him with a pure heart, without stain." ${ }^{50}$ An aunt expressed her confidence that her dead nephew "added the patina of Martyrdom to his baptismal Innocence." 51 The abbé Bresciani even claimed that "the only fear to which these Christian heroines show themselves vulnerable" was not the thought of their sons' deaths but rather of "the terrible dangers to which the innocence and piety of these dear warriors, who had left so pure and so innocent, might be exposed." 52 The model Zouave was one whose childlike purity remained fundamentally unchanged, even as he was tested in battle. The idea that Zouave bodies achieved a brief adulthood through the experience of excruciating pain rather than of sexual pleasure runs through their stories.

The physical suffering of the individual soldier was crucial to his ultimate, mysterious victory, and Zouave narratives dwell on the experience of pain. They celebrate lingering deaths and rejoice in the dying man's full consciousness that enables him both to receive the sacraments and to recount his death agony. Joseph Guérin's biographer depicted his last days in excruciating detail. A comrade, Monsieur de Perrodil, found Guérin on the battlefield, cold as ice and stripped not only of his uniform but also of his sacred medals and his

aves was probably reinforced by the Zouaves' reputation within the French army for military excellence combined with lax discipline (Boutry, "Zouaves, pontifical," 1642).

${ }^{46}$ Allard, Le Volontaire Joseph-Louis Guérin, 46.

${ }^{47}$ Ibid., 50.

${ }^{48}$ Daniel to Richard, n.d., AHAP, I DX7, folder A, letter 29.

${ }^{49}$ Quoted in Guenel, La Dernière Guerre, 68-69.

${ }^{50}$ Mme Terrasse to abbé Daniel, n.d. [1865], AHAP, I DX7, folder A, letter 7; Mme d'Héliand, quoted in Delmas, Neuvième Croisade, 235.

${ }^{51}$ Félicité de Laville Leroulx to Richard, November 14, 1867, AHAP, I DX7, folder A, letter 21a.

${ }^{52}$ Bresciani, Le Zouave pontifical, 63. 
crucifix. Believing him dead, Perrodil kissed his "pure face.” Guérin, however, survived several more days, making a brief recovery in hospital that allowed him to perform acts of charity, offering comfort to other wounded men, writing letters for them, and helping them to prepare for their own deaths. Gangrene caught up with "this little angel on earth," and he spent his final day in agony, fully conscious, begging his companions to pray for him and rejoicing at being called to God. ${ }^{53}$ Other accounts have Guérin monitoring his pulse and temperature, refusing the solace of wine, and offering each individual pain of his agonized body to God. ${ }^{54}$ Similar, if less elaborate, deathbed scenes were the climax of most biographies, like that of Bernard de Quatrebarbes, fatally wounded at Monterotundo. He underwent an amputation but remained conscious, recited the rosary with his sister, and fretted because his lost arm would prevent him from returning to the field. His biographer believed that the suffering of this "noble and holy victim" served a purpose: "The voice of your blood wins victory for your brothers in arms." 55 These vignettes were often reprinted from one account to another. Anatole de Ségur's Martyrs de Castelfidardo, for instance, a compilation of pious deathbed scenes intended to demonstrate that the Zouaves "achieved even more greatness in the hospital than on the battlefield," became the source for many subsequent accounts. ${ }^{56}$

Because the Zouave's main purpose was not to win but to suffer, illness could produce a calvary comparable to battlefield wounds. Sickness, in addition to being common in Zouave ranks, posed none of the moral problems of being killed while killing on the battlefield. The abbé Daniel maintained a "Book of the Dead" with a page to record the edifying details of each Zouave death, and he reassured many young men, expiring from cholera or infection, that they were nonetheless martyrs for their deaths in hospital. ${ }^{57}$ In the pages of Daniel's journal, a Zouave who was too weak for anesthetic endured the amputation of his gangrened limb, while another suffered simultaneously from smallpox, typhoid, pulmonary congestion, skin abscesses, and gangrene: even as his body began to decompose, he received communion several times and extreme unction twice. ${ }^{58}$ Daniel praised the Zouaves' care for victims of the cholera epidemic in the summer of 1867: when families abandoned the sick and pharmacists refused to visit their patients, Zouave charity was unflagging. ${ }^{59}$

${ }^{53}$ Allard, Le Volontaire Joseph-Louis Guérin, 56-89.

${ }^{54}$ Delmas, Neuvième Croisade, 231. See also Bresciani, Le Zouave pontifical, chap. 19.

${ }^{55}$ Bernard de Quatrebarbes (Angers, 1868), 32-41, 32.

${ }^{56}$ Ségur, Martyrs, 51. For instance, Athanase de Charette, Souvenir du régiment des zouaves pontificaux, vol. 2 (Tours, 1875).

${ }^{57}$ Allard, Les Zouaves pontificaux, ou journal, see, e.g., 41-43, 64, 78-79, 84.

${ }^{58}$ Ibid., 217-18.

${ }^{59}$ Ibid., 273; and Laurent Bart-Loi, Au service du Pape et de la France: Catherin, 1861-1870 (Lille, 1901), 144-45. 
By the end of July Daniel noted that he had lost twelve Zouaves, including one who died "like an angel." 60 The chaplain Gerlache similarly valued the suffering of the sick; his account of the fall of Rome closes with the story of Alphonse Delva, a Belgian Zouave, who missed the battle because of smallpox. He was taken prisoner and thrown into a cell for two days with a little black bread and water. When his fever rose he was removed to hospital, but as his captors moved him through the city, the local population set upon him, kicking him and burning him with their cigars. Delva played no part in the defense of Rome, but Gerlache considered his suffering - and especially his desire to confess his sins and receive absolution as soon as he returned to consciousness - to be emblematic of Zouave anguish. ${ }^{61}$

All in all, these were strange soldiers: seeking sainthood, anxious to lose, savoring pain. And they were reluctant to kill: Zouave stories usually describe Zouaves dying, almost never Zouaves killing. Zouave victimhood had many facets: they were betrayed by dastardly Piedmontese who rejected the rules of civilized warfare and violated by misguided Italians who mocked them as mercenaries or who looted their wounded bodies. In a typical account of Zouaves in battle, Jules Watts-Russell was shot and killed as he tended to a wounded Garibaldino. ${ }^{62}$ Several authors quoted Georges d'Héliand's letter to his mother in which he swore that he would never retreat but also worried that he lacked adequate target practice to shoot accurately. ${ }^{63}$ Anatole de Ségur included one of the rare descriptions of Zouaves killing: he quotes an unnamed soldier's account of Castelfidardo, in which Zouaves peer through the blinds of an abandoned house at their enemy, thinking "Ah! will I be able to shoot at that poor child? He may have a mother who will weep for him.... And look at that one! He looks so young and sweet!" According to Ségur, "More than once this exquisite pity stopped the avenging ball in the barrels of their rifles." ${ }^{4}$ The Zouaves were lambs sent to the slaughter: "young lambs who became terrible lions, children who became giants." ${ }^{\circ 5}$ The grandeur they achieved, however, was based on a combination of an adult male body and childlike virtues that precluded effective soldiering.

It is perhaps tempting to locate the Zouave within stereotypical nineteenthcentury gender roles by describing him as effeminate, but such a label does little to explain the meaning of Zouave suffering or its appeal to French Catholic audiences. The Zouaves were not simply effeminate men looking for a

\footnotetext{
${ }^{60}$ Daniel to Richard, July 3, 1865, AHAP, I DX7, folder A, letter 3.

${ }^{61}$ Gerlache, Les Derniers Jours, 44.

${ }^{62}$ Bart-Loi, Au service du Pape, 164.

${ }^{63}$ Ségur, Martyrs, 92-93; Delmas, Neuvième Croisade, 38-39.

${ }^{64}$ Ségur, Martyrs, 49.

${ }^{65}$ Bernard de Quatrebarbes, 20.
} 
place in a feminized church. Their stories take seriously both the manliness of their military vocation and the gentle innocence at the heart of their sanctity; they are complementary, not opposite, qualities. The Zouave martyr suggests that religious sentiment, as much as categories like class, inflected gender identity. Young men whose world not only existed on a horizontal plane that included France and Rome but also had a vertical dimension reaching to God created possibilities for gendered self-expression that were not available to all of their fellow Frenchmen. They not only could but in fact could only be brave and disciplined soldiers when faced by their fellow men, in particular by unbelieving or deluded Piedmontese. Before God, however, and before earthly representations of God's love such as that offered by their mothers, they could only be submissive and loving.

\section{WOMEN's SHARE OF SUFFERING}

Zouave stories derived much of their appeal from the way in which they located women as well as men in the Roman drama of sacrifice and expiation. Mothers, especially, shared intensely in Zouave agony, and several compilers of martyrologies dedicated their work to the pious women who "were also part of that army." ${ }_{66}$ The women who figured in Zouave stories were Catholic femmes fortes, but not because they found their way into the public sphere or discovered their own autonomy. Theirs is a very different kind of female strength; these women achieved self-transcendence, a suppression of their own will so that God's will might be done through them. In a recent article on Quaker women, Phyllis Mack has observed that feminist theory has not provided itself with the tools to understand religious women who seek the elimination, rather than the realization, of self. In particular, Mack argues, women cultivating pain for purposes of moving away from self and toward God often escape our comprehension. ${ }^{67}$ Like the Quaker women Mack studies, these Catholic women, the female characters in the Zouave drama, were not interested in their own agency, but in God's.

If the Zouave was the narrative link between the Catholic faithful and the pope, then the Catholic woman, seeking to share in the pain of martyrdom, was the figure who most closely resembled the Zouave story's reader. The Zouave himself was an unrealizable model; hardly any readers of this literature would respond by going to Rome and themselves joining the papal forces. Zouave stories were not recruitment tracts: they never called for new volun-

\footnotetext{
${ }^{66}$ Eugène de Walincourt, Les Zouaves pontificaux: Mentana, Rome, campagne de l'Ouest (Lille and Paris, 1873), 24.

${ }^{67}$ Phyllis Mack, "Religion, Feminism, and the Problem of Agency: Reflections on Eighteenth-Century Quakerism," Signs 29 (2003): 149-77.
} 


\section{Harrison}

teers, and they provided no information on how to enlist. Going to Rome was not necessary because the Zouave sacrifice was expiatory and symbolic: suffering, not victory, was its purpose. Mothers' pain, rather than Zouave service, was the model available for readers' imitation. The Zouave story asks its reader - male or female - to identify with the mother's role in another significant example of the ways in which Catholic devotion inflected nineteenthcentury gender roles. Neither men nor women needed to engage in active military heroics to demonstrate their loyalty to the church; passive suffering sufficed for all.

Mothers were indispensable witnesses, even at a distance, to their sons' sufferings. Mothers left behind in France experienced mysterious bonds to their sons dying in Italy: "Mary's maternity, her humility, her chastity, and her participation in all of the mysteries of Christ ... are perpetuated in [these] Christian women." ${ }^{68}$ Madame de Quatrebarbes, confined to her sickbed in France, learned of her son Bernard's death and experienced "a mystery of pain and resignation that human language cannot express and whose extent only God can understand." ${ }^{69}$ Last words often united mothers and sons: Paul de Parcevaux's final wish was that his soul be given to God, his body to Our Lady of Loreto, and his heart to his mother. ${ }^{70}$ According to one account, when Paul's mother received her son's heart, she "seemed to hear from the urn a last farewell whisper, like the sound of a supreme kiss; it was a consoling promise of a quick and eternal reunion!" 71 Mizael le Mesre de Pas also died at Loreto, praying that his pain should be joined with the Virgin's and laid at the foot of the cross and begging Mary to look after his own mother. ${ }^{72}$ Raoul Terrasse, his mother's only son, asked the chaplain to "tell her I'm going to heaven, and it's thanks to her, because of the principles she taught me." ${ }^{73}$

Sisters might also play a role in the drama of Zouave suffering; wives and other female relatives did so less often. Xavier Bouquet des Chaux's biographer was an unmarried female relative, probably a sister, who never identifies herself but who speaks authoritatively about his family life from earliest childhood and who accepts it as her duty to commemorate her brother's Zouave service and his subsequent vocation and priesthood. ${ }^{74}$ Emmanuel Dufournel's

${ }^{68}$ Ségur, Martyrs, 263-64.

${ }^{69}$ Bernard de Quatrebarbes, 41.

${ }^{70}$ Delmas, Neuvième Croisade, 221-22.

${ }^{71}$ Bresciani, Le Zouave pontifical, 293. In 1864 the abbé Daniel prayed before Parcevaux's heart at Saint-Pol (Allard, Les Zouaves pontificaux, ou journal, 121).

${ }_{72}^{72}$ Delmas, Neuvième Croisade, 86-87.

${ }^{73}$ Allard, Les Zouaves pontificaux, ou journal, 266-67; Bart-Loi, Au service du Pape, 146.

${ }^{74}$ The letter at the beginning of the biography from the Bishop of Moulins in praise of the subject is addressed to "Mademoiselle" (Saint-Gérand, Vie de Xavier Bouquet des Chaux). 
sister rushed to his bedside but arrived too late; she nonetheless found a role for herself in the humble activity of nursing her brother's dying orderly. ${ }^{75}$ Catherine d'Héliand's vocation was revealed as she knelt with her mother on the "earth stained with her brother's blood" at Castelfidardo and decided that she, too, would embrace sacrifice. As a sister of Saint Vincent de Paul, an order whose members nursed fallen Zouaves after Castelfidardo, Catherine would become a "martyr of charity." 76

Wives fit less comfortably in the Zouave narrative; only in fiction does the Zouave feature as romantic hero. The Zouaves were often young men, and a high percentage of them entered seminary after returning to France, so there were not that many wives about whom to write. The wives who do appear, however, find themselves largely, if not completely, erased from the narrative. Gaston du Plessis de Grénédan postponed his marriage because, when in Paris to organize the ceremony, he was, in his own words, "seduced" by the idea of following "the banner of the blessed Virgin." 77 Like Zouave mothers, Madame de Pimodan, wife of a Zouave general, could tell when her husband was dead: she knew that the woman who attempted to break the news gently by telling her he had been taken prisoner was lying. Her response to her loss drew from the repertoire of Zouave motherhood: she embraced her four-year-old son and told him that he too would be a soldier for the pope: "You will die too, if necessary, for the Holy See, just as your father has done." ${ }^{78}$ The biography of Henri de Verthamon is unusual in the extensive role it accords his wife; his father-in-law compiled the text, drawn largely from their correspondence. Verthamon married in 1862 after his Zouave engagement at a moment when Rome appeared secure, but in 1870 he left his wife and children to return to the Zouaves. His biography, however, concludes with a vignette featuring his mother, who learns of his death from the nun who nursed him: "We attended the death of a saint! You are so fortunate, Madame, to have such a son." 79 Mothers eclipsed wives in Zouave stories; the most fundamental bond was always that between mother and son, mediated by the Virgin.

Marriage was a problematic relationship primarily because it tied the Zouave to a future as husband and father rather than leaving him free to die repre-

\footnotetext{
${ }^{75}$ Derély, Vingt-Quatre Heures, 60-61.

${ }^{76}$ In Rome to enter her convent, Catherine was also present at the deathbed of her cousin (Bernard de Quatrebarbes, 37).

${ }^{77}$ Delmas, Neuvième Croisade, 32.

${ }^{78}$ Ségur, Martyrs, 68-69; Delmas, Neuvième Croisade, 237-38. Madame de Charette appears frequently in the pages of Daniel's journal as she marries the commandant, contributes to the social life of the Zouaves, gives birth to a son, and tragically dies shortly afterward. Her death never became martyrdom, however, and she is completely absent from later accounts (Allard, Les Zouaves pontificaux, ou journal, 98, 103-4, 105, 133-34).

${ }^{79}$ Henri de Verthamon, 120.
} 


\section{Harrison}

senting the universal suffering of Catholics. The sexually innocent Zouave boy, who belonged to his mother and to the Virgin and who gave himself to the church, was a more accessible symbol than a man like Henri de Verthamon who left a wife and children in order to seek martyrdom in Rome. One might well see Verthamon's sacrifice as irresponsible rather than selfless. Oscar de Poli acknowledged that many of his fellow soldiers had fiancées at home, but he depicted them as chaste sisters: "children of sixteen or seventeen, with whom they [the Zouaves] had grown up, and to whom they had sworn the kind of holy affection that absence merely strengthens." ${ }^{80}$ The fictional Zouave Olderic similarly transforms his fiancée Jacqueline, addressing her in letters from Rome as "my beloved sister" since he cannot call her either "wife" or "Mademoiselle." "It is probably no accident that the Zouave fiction featuring the most conventional marriage plot was Madame de Ségur's Après la pluie, published after the fall of Rome. With Pius IX as the prisoner of the Vatican after 1870, the Zouave was no longer needed as the symbol of active Catholic engagement in the struggle to preserve papal sovereignty, so Jacques is free to marry Genèvieve and to pursue something other than martyrdom.

Zouave texts highlighted mothers as Catholic femmes fortes, not least because they stood in such contrast to the delicacy and weakness of their Zouave sons. In the story of the heroic combat to save temporal sovereignty, the Zouave mother seems to possess some of the ferocity that is so conspicuously absent among the fighting men. Madame de Charette, for instance, with five Zouave sons, knelt at the pope's feet and declared that if girls could carry swords, she would sacrifice her daughters as well. ${ }^{82}$ In France, women "enrolled" themselves in the cause, joining, for instance, the "holy militia of the Daughters of the great Saint Vincent de Paul," as one woman described her vocation. ${ }^{83}$ Nuns like the Clares of Amiens called themselves "pontifical Zouaves" and vowed that their prayers, their charity, and their silence would be weapons in the pope's arsenal. They sent their testimonies to Rome with careful accounts of precisely how many hours of devotion and prayer they were contributing to the papal armory. ${ }^{84}$ In 1868 Bernadette Soubirous, the visionary of Lourdes, and her sisters at the convent of Saint-Gildard welcomed the papal nuncio by informing him that they were "soldiers of duty, Zouaves of prayer." 85

${ }^{80}$ Oscar de Poli, Souvenir du bataillon des zouaves pontificaux (Paris, 1861), 107.

81 This transformation from lover to sister is all the more remarkable since Olderic's early letters simply address her as "Jacqueline" (Bresciani, Le Zouave pontifical, 46).

${ }^{82}$ Delmas, Neuvième Croisade, 378.

${ }^{83}$ Richardine de la Perrière to Pius IX, March 27, 1862, in Horaist, La Dévotion, 401-2.

${ }^{84}$ Sister Saint-Pierre to Pius IX, July 5, 1869, in Horaist, La Dévotion, 429-30.

${ }^{85}$ René Laurentin, Bernadette Speaks: A Life of Saint Bernadette Soubirous in Her Own Words, trans. John W. Lynch and Ronald DesRosier (Boston, 2000), 469. 
Much later, a sick and feeble Bernadette wrote from her bed to Pius IX; although she required assistance to support the portable desk, Bernadette nonetheless reminded him that she was, "though unworthy, your Holiness' little Zouave." ${ }^{86}$ Teaching sisters enrolled their pupils as "Zouaves in prayer." Thérèse de Chateaurocher, age fifteen, whose brother was serving in Rome, promised that she too was "ready ... to spill [her] blood for such a great cause." Another schoolgirl, Marie Tocqueboeuf, wrote: "Under the watchful gaze of Mary, my tender mother, I enlist for three months in the pontifical Zouaves. Oh God, give me the strength I need to stand by my promise. Oh Mary my mother, bless this resolution and her who makes it." ${ }^{177}$ Marie and her classmates signed their testimonies in their own blood.

Key to these female Zouaves' enlistment was their willingness to violate the norms of daily life: nuns stockpile symbolic arms, girls shed their blood, and mothers find comfort in their sons' deaths. This last theme-maternity sacrificed - runs through Zouave literature with remarkable consistency. Georges d'Héliand's mother, learning of her son's death, wrote that she had "offered him to God as a sacrifice, and God had deigned to accept him. ... Abandoning Georges totally into the loving hands of divine Providence [les mains amoureuses de la divine providence] has been for me a source of great peace." 88 When the father of a prospective Zouave, in a play written for performance in boys' schools, is forced against his will to allow his son to go to Rome, he recognizes that he was fighting a losing battle all along. The boy's mother, on her deathbed, had pledged her son to God, so that his father ultimately had no choice but to ask God for the courage of Abraham, to sacrifice his son's life. The boy leaves for Italy, and his father consoles himself that his dead wife's soul will rejoice in heaven. ${ }^{89}$ Joseph Rialan's mother drew explicitly on the tradition of strong Catholic womanhood in her response to her son's death: "I don't know what the mothers of the early martyrs said.... The Church is still the Church and Brittany is not lost because femmes fortes still raise sons who

\footnotetext{
${ }^{86}$ The December 17, 1876, letter was written at the request of Monseigneur de Ladoue, Bishop of Nevers, who delivered it to the pope. André Ravier, ed., Les Ecrits de Sainte Bernadette et sa voie spirituelle (Paris, 1980), 448-56, presents the full text and its various drafts. See also Laurentin, Bernadette, 469-71. My thanks to Philippe Boutry for this reference.

${ }^{87}$ Thérèse de Chateaurocher, with the pupils of the Sacré Coeur de Poitiers, January 1, 1869, and Marie Tocqueboeuf with the school from Bourg Saint Andéol, 1868, in Horaist, La Dévotion, 445, 428.

${ }^{88}$ Quoted in Bresciani, Le Zouave pontifical, 280-81.

${ }^{89}$ L'abbé M——, Le Zouave pontifical (Lyon, 1868), 41, 52-53, 57. Zouave stories featured in several plays written for school performance, although more commonly after 1871 .
} 
are worthy of our ancestors and also worthy to die for our God." ${ }^{90}$ The role of the Zouave woman was to be a modern mother of the Maccabees, sacrificing her sons to torture and death and violating social norms at God's command.

Scholars have noted that Catholic virtue broadened the scope of women's activities and created new forms of female autonomy, largely in teaching, nursing, and charitable organization. ${ }^{91}$ The claim, based particularly in Marian devotion, that women were the pious sex and the principal victims of modern society was an important means of access to the public sphere for women in Catholic countries. The militant women of the Zouave stories, however, were not looking for a greater role in public life, but for a more intense and intimate relationship with God, mediated through the papacy and their sons, its defenders. Indeed, these women sacrificed precisely those things—children and family life - that were generally proclaimed to be the foundations of female Catholic virtue. The heroines of Zouave stories, as much as the heroes, refuse to conform to the conventional gender roles of popular fiction. Their lives do not focus on marriage, either on making good marriages or on achieving autonomy within marriage, and their husbands, the fathers of Zouaves, play a minor role. The women who associated themselves with the Zouave cause do not fit comfortably in scenarios of the bourgeois household because they saw their own roles - and their families' - within the larger context of a suffering church. These women refused to limit their horizons to the conjugal household, but they found the world of social activism or national politics similarly restrictive: both home and nation were incidental settings in the real drama of human salvation.

Zouave mothers suggest a new line of inquiry into the historical relationship between women and religious faith and, in particular, into the links between nineteenth-century ultramontane piety and the mobilization of women. Scholars have noted that an unprecedented level of female vocation and activism accompanied the "Romanization" of nineteenth-century Catholicism, ${ }^{92}$ but the nature of the relationship between female numbers and ultramontane Catholic culture remains murky. The significance of women in the Zouave narratives

${ }^{90}$ Quoted in Robert Oheix, Joseph Rialan, sergent aux zouaves pontificaux (Nantes, 1868), 332-33.

${ }^{91}$ Sarah Curtis, "Charitable Ladies: Gender, Class and Religion in Mid-Nineteenth Century Paris," Past and Present, no. 177 (2002): 121-56; Hazel Mills, "Saintes Soeurs and Femmes Fortes: Alternative Accounts of the Route to Womanly Civic Virtue and the History of French Feminism," in Wollstonecraft's Daughters: Womanhood in England and France, 1780-1920, ed. Clarissa Campbell Orr (Manchester, 1996), 13550; Langlois, Le Catholicisme au féminin.

${ }^{92}$ Most recently, Christopher Clark in "The New Catholicism and the European Culture Wars," in Culture Wars: Secular-Catholic Conflict in Nineteenth-Century Europe, ed. Christopher Clark and Wolfram Kaiser (New York, 2003), 19-20. 
of the Roman Question suggests a need to look closely at the content of female piety and at the vehemence with which these women sought to lose themselves in the grand martyrdom of their church and its sons. For these women, autonomy was tantamount to godlessness, and domesticity was too limited a cause to which to dedicate themselves. Repeatedly, they state their willingness to empty themselves and to sacrifice their maternity in order to reestablish God's order in the world. Women's role in the development of ultramontane piety in nineteenth-century Europe clearly involved more than mere numbers of female religious vocations or charitable monies spent.

Just as it is inadequate to refer to the Zouaves as effeminate men, it is similarly unsatisfactory to describe these women as assuming a "masculine role," as Richard D. E. Burton does in his account of Thérèse Martin-Saint Thérèse of Lisieux - another woman who described herself as a Zouave. ${ }^{93}$ To fill the Catholic world with men performing effeminacy and strong women grasping male attributes is to make Catholicism a bizarre inversion of "normal" society. In doing so we borrow nineteenth-century anticlerical language of gender inversion, and we reify a bourgeois world of separate spheres in which male and female are obvious and natural categories. ${ }^{94}$ Zouaves and their mothers recognized the social and familial norms of nineteenth-century France, and they recognized when those norms were irrelevant. They did not contest social norms so much as ignore them. Their stories open the door to an exploration of what gender might mean to people whose worldview encompassed not only the social but also the divine. In nineteenth-century France, God demanded more of many women than society did, and as scholars we would do well to consider the significance of the women who believed that they put divine command ahead of social stricture.

\section{SAINTS AND THE SUPERNATURAL}

Even beyond death, the Zouave continued to act as a link that bound French Catholics to their martyred church. The final act of the drama cast the Zouave as heavenly intercessor for his grieving family, especially for his mother. References to saintly deaths were ubiquitous in the Zouave literature, but by no means were they mere figures of speech or hyperbolic descriptions of a Christian death attended by priest and sacraments. Observers and loved ones at home took the possibility of sanctity very seriously indeed, and they believed that

\footnotetext{
${ }^{93}$ Although long after the fall of Rome (Burton, Holy Tears, 29-30).

${ }^{94}$ On the anticlerical rhetoric of gender inversion-effeminate priests encouraging manly behavior in women - see Thomas Kselman, "The Perraud Affair: Clergy, Church, and Sexual Politics in Fin-de-Siècle France," Journal of Modern History 70 (1998): 602-3.
} 
Zouave intercession would produce miracles: "Innocent victim, chosen martyr of the Church, sweet and holy Mizael, pray for us!"95 Everyone concerned with the Zouaves carefully scrutinized deaths, looking for signs of holiness. This essay concludes with an examination of the miraculous results of Zouave devotion, focusing particularly on two cases of putative sainthood: Joseph Guérin, with whom I began, and Joseph Rialan, whose aunt desperately wanted to believe in his holiness. The claims of Zouave saints are evidence of the defiant belief in the supernatural that characterized ultramontane Catholics, and they remind us that both men and women lived in the expectation of divine intervention. The Catholics who believed that their Zouave martyrs acted as intercessors for them were confident that divine intervention was not rare and that it could happen in their lives.

Guérin and Rialan's claims to sainthood rested on virtuous lives, martyrs' deaths, and the performance of posthumous miracles. Guérin's miracle, recounted at the beginning of this essay, involved the cure of the blind, paralyzed Italian girl; the abbe Daniel believed that the pope was investigating these claims. ${ }^{96}$ The abbé Allard, who had known Guérin in Nantes, published his biography within months of the young man's death in 1860, and other authors quickly picked up his story. The Baron de Charette offered images of Guérin to comfort dying Zouaves under his command.${ }^{97} \mathrm{By}$ the time Philibert Catherin included an account of Guérin's cure in a letter to his brother (probably 1863), he knew that miracles had occurred in Brittany as well as in Rome, and he had heard that the pope kept a bust of this "holy Zouave" in his rooms. ${ }^{98}$ Daniel, on leave in Brittany in 1864, was among the thousands of visitors to Guérin's tomb. ${ }^{99}$ Locals said that a young shepherdess had been cured by a lock of Guérin's hair, and the Bishop of Nantes, while careful not to pronounce a miracle, admired "the marvelous coincidence between prayer and simple contact with a relic of our little Zouave and a cure that is either instantaneous or that follows a novena." 100

\footnotetext{
${ }^{95}$ Ségur, Martyrs, 83. Both lay and clerical writers used this language of sanctity: see also the letter from the abbé Peigné noting that the Zouaves had lost twenty-two men at Mentana, including "a few saints, the flowers of the regiment's purity and piety" (letter to Richard, November 10, 1867, AHAP, I DX7, folder A, letter 27).

${ }^{96}$ Daniel to Richard, June 13, 1863, AHAP, I DX7, folder A, letter E, and January 9, 1862, letter G.

${ }^{97}$ Delmas, Neuvième Croisade, 335; Allard, Les Zouaves pontificaux, ou journal, 210.

${ }_{98}$ Bart-Loi, Au service du Pape, 90-91.

${ }^{99}$ Marcel Launay, Le Diocèse de Nantes sous le Second Empire: Monseigneur Jacquemet, 1849-1869, 2 vols. (Nantes, 1982), 2:738, notes that five hundred people visited the tomb every Sunday shortly after his burial in April 1861. For Daniel's visit, see Allard, Les Zouaves pontificaux, ou journal, 120.

${ }^{100}$ Monseigneur Jacquemet, in a January 1862 letter to the Bishop of Blois, quoted
} 
Shortly after Joseph Rialan's death in 1867, his aunt contacted Monseigneur Richard in Nantes with news that she stopped just short of describing as miraculous. The story of her nephew's death was making a great impression on the local population, she wrote; in particular, it had had a beneficial effect on "a soul that had turned away from God." A gentleman from Vannes who had heard of young Rialan's death, she had been told, had not actually converted but was said to be on the verge of doing so. There were also crowds of peasants who were planning to attend his burial. In this situation, the aunt needed Monseigneur Richard's advice: should she arrange for the publication of a biography of her nephew? As painful as it would be to her to see family stories published, did she not have some obligation to make available edifying details from his life? At three years old he had spontaneously knelt before a Corpus Christi procession and had emptied all the coins in his purse into the hands of a beggar child - in her letter, his aunt shaped the boy's life into the beginnings of a hagiography. ${ }^{101}$ In her next letter she raised the possibility that God might allow them the great happiness of seeing Joseph as he had been in life, his body untouched by corruption, and she noted that local people had been asking her when Joseph's body_- "or his relics, as I have heard several times"would arrive. ${ }^{102}$

Rialan's aunt pursued her project of commemorating her nephew with a biography, and she cooperated with his school friend Robert Oheix in the production of Joseph Rialan, sergent aux zouaves pontificaux, which appeared in 1868. Lengthy excerpts from Rialan's letters to his parents, to his aunts, and to Oheix make up a large portion of the text, which confirms the importance of the bond between the Zouave and his female relations. At the end of the book, Oheix thanks Madame Rialan and her sisters, Joseph's aunts, for their assistance. Unfortunately, he says, Joseph's father "judged it inappropriate to publish" his son's private correspondence. Even though Monsieur Rialan "formally expressed" his opposition to the book, Oheix decided that the letters-"Joseph Rialan in his own words"-were crucial to the biography and

in Launay, Le Diocèse, 2:740 n. 229. Daniel noted that Italian peasants took away grass and dirt from the battle site at Castelfidardo (Allard, Les Zouaves pontificaux, ou journal, 95). By 1875, enthusiasm for Guérin seems to have cooled: Athanase de Charette (who had handed out Guérin's picture) indicated in his biographical notices of Zouave dead that Guérin's tomb had become a site of pilgrimage for Bretons, but he mentioned no specific miracles (Charette, Souvenir du régiment, 2:104).

${ }^{101}$ Félicité de Laville Leroulx to Richard, November 28, 1867, AHAP, I DX7, folder A, letter $22 b$

${ }^{102}$ December 15, 1867, AHAP, I DX7, folder A, letter 23a. Walincourt, Les Zouaves pontificaux, 135, quotes a statement by two priests indicating that they found Rialan's body two days after his death and that he lay peacefully, as if asleep, with no sign of decay. Recognizing the possibility that the Zouave might be a "treasure" not only for his family but for the entire church, they had four witnesses sign the statement. 
published them anyway. Joseph's womenfolk received their hagiographic tribute to the dead young man; his father got nothing but the author's apologies. ${ }^{103}$ In this case, at least, when sanctity was at stake, a bourgeois père de famille proved singularly unable to exert either his authority over women or his property rights over family correspondence. ${ }^{104}$

Guérin and Rialan were not the only Zouaves associated with miraculous events: accounts of conversions, hints at preserved bodies, and confidence in Zouaves' role as heavenly intercessors run through the literature. ${ }^{105}$ Probably the best-known Zouave was Maximin Giraud, the boy who had encountered the Virgin at La Salette in 1846 and who generated great enthusiasm when he joined up; observers hoped that the garrison would witness a sequel to his childhood visions. ${ }^{106}$ Even relatively obscure Zouaves might also become the objects of devotion for family and friends. Henri Pascal's parish priest wrote to the dead Zouave's brother that he had "recommended his [Henri's] soul to the God of mercy," but, he said, "I think I would do better to recommend my own [soul] to his intercession, because he has no doubt already received the martyr's palm." ${ }^{107}$ Paul Saucet's death following illness inspired Madame de Jurien to wash his corpse herself and dress it in white since it was, she said, the body of a saint. ${ }^{108}$ Julian Watts-Russell, son of an Anglican minister who had converted to Catholicism, never displayed signs of rigor mortis and might, thanks to the intensity of his prayers for the conversion of nonbelievers, have been responsible for bringing some Garibaldini back to God. ${ }^{109}$ The Zouaves and their supporters lived in a world of divine presence that might make itself felt at any moment by opening communication between the dead and the living.

Clerics, as well as laymen, followed the possibility of Zouave saints with interest and were actively involved in the effort to canonize Guérin and Rialan. The abbé Allard, in his biography of Guérin, makes no explicit claims for sainthood in his own voice, although he quotes many others who do not hesitate to label Guérin a saint. Allard's characterization of the Zouave's life as a

${ }^{103}$ Oheix, Joseph Rialan, 376.

${ }^{104}$ On letters as property, see Cécile Dauphin, Prête-moi la plume .. . les manuels épistolaires au XIXe siècle (Paris, 2000), 60-61.

${ }^{105}$ On the question of intercession, see esp. Guillaume Cuchet, "The Revival of the Cult of Purgatory in France (1850-1914)," French History 18 (2004): 76-95.

${ }^{106}$ Daniel to Richard, May 12, 1865, AHAP, I DX7, letter 10. Philibert Catherin was particularly impressed that the young man "hoped to remain incognito" before he finally had to admit to his captain that he was "Maximin de la Salette." Quoted in Bart-Loi, Au service du Pape, 118. To everyone's great chagrin, Giraud was expelled from the Zouaves, apparently for drunkenness.

${ }^{107}$ Walincourt, Les Zouaves pontificaux, 142.

${ }^{108}$ Allard, Les Zouaves pontificaux, ou journal, 57.

${ }^{109}$ Walincourt, Les Zouaves pontificaux, 151-52. There is some confusion as to his first name; he is certainly the same man cited above as Jules Watts-Russell. 
"treasure" to be shared with others, however, makes it clear that the biography is an argument for Guérin's sanctity. The chaplain Daniel explained that he was able to find Rialan's corpse immediately because "on the wagon that carried [the bodies] . . . his face shone in the midst of all the others, with a purely supernatural beauty." ${ }^{110}$ Robert Oheix carefully documented the role of clerics in making a case for Rialan's sainthood. Oheix quotes a letter from a priest, probably Daniel, who suggests that God sent him to the battlefield in order "to recover the precious remains of a saint from the pell-mell of the common grave." 111 Zouave chaplains, seeing how local people looking for relics stripped Rialan's body of his scapular, his sergeant's stripes, and his hair, decided that he should not be buried with the other fallen men. The priests who opened the coffin when it arrived in Rome noted that Rialan's limbs remained as supple as in life and that there was no odor or other evidence of decomposition. Twelve days after the battle two priests visited the site of Rialan's death and found a pool of blood that had not dried. ${ }^{112}$ Pius IX, according to Oheix, spoke of Rialan and Guérin in the same breath and wept at their fate. ${ }^{113}$

Nothing seems to have come from this initial enthusiasm for Zouave saints; given the controversies in the Vatican concerning both the Zouaves and the appropriate response to the fall of Rome, the hierarchy's lack of interest is not surprising. There is no evidence that Monseigneur Richard or the Bishop of Nantes encouraged Rialan's aunt, nor, as far as I know, were Joseph Guérin's miracles seriously investigated. The abbé Peigné, who appears in Oheix's volume as a firm believer in Rialan's sanctity, was more cautious when he returned the Zouave's body to his family. Joseph's relatives should take comfort, he said, in knowing that the body would be a "source of blessings for our work and a constant exhortation to our young men to love duty and sacrifice," but he claimed no miraculous properties for it. ${ }^{114}$ Some later writers were careful to note that when they referred to their lost loved ones as "saints," they used the word as it appeared in common parlance, without making theological claims. ${ }^{15}$ Nonetheless, it seems clear that when French Catholics imagined

${ }^{110}$ Allard, Les Zouaves pontificaux, ou journal, 342.

${ }^{111}$ Quoted in Oheix, Joseph Rialan, 338.

${ }^{112}$ Ibid., 329-30.

${ }^{113}$ Ibid., 351.

${ }^{114}$ Abbé Peigné to Richard, November 10, 1867, AHAP, I DX7, folder A, letter 27.

${ }^{115}$ See, e.g., Saint-Gérand, Vie de Xavier Bouquet des Chaux, vii, and the statement with which J.-S. Allard, Daniel's editor, prefaces his volume: "in reporting facts that appear miraculous, but on which the Church has not pronounced itself, and in referring to persons who have not yet been elevated on our altars as saints" he submits himself fully to the Holy See and disavows any statement that might be contrary to Church teaching (Les Zouaves pontificaux, ou journal). 
martyr Zouaves as a link in the chain that bound them to heaven, they expected a strong and efficacious bond, with material as well as symbolic consequences.

The stories of the Zouave saints add a new dimension to scholarship on nineteenth-century Catholic supernatural encounters with the divine. Recent work on Marian apparitions, in particular, has familiarized us with a world in which women and children have special access to visual and physical contact with holy persons. Mary's maternal love rewarded the visionaries, who were often poor, abandoned, and vulnerable. ${ }^{116}$ Sites like La Salette and Lourdes have come to define the nineteenth-century divine encounter: poor women and children find, in Mary, a mother who consoles them for the lack of affection and stability in their own families. Some elements of this scholarship resonate with the Zouave narratives: Joseph Guérin appeared to a young girl, and it was her healed body that testified to his sanctity. But for the most part the Zouave saints tell a different story: about the possibilities of adult male piety, for instance, and about the glorification of earthly, as well as divine, motherhood.

The stories of the Zouaves' childlike innocence and candor were powerful precisely because they were not children, nor were they powerless. The Zouaves were real soldiers, who might become heads of households or priests if God did not claim them for his own. Zouave narratives emphasize young men's renunciation of privilege: they polished their own boots and packed and carried their own kits and did the work that their peers would leave to servants. ${ }^{117}$ These were young men who might, like the fictional Olderic, have been incapable of folding their own handkerchiefs before their Roman experience. ${ }^{118}$ They could certainly have picked other, less strenuous, occupations that would not have led them to agonizing deaths in Italy. They chose, however, to sacrifice the privileges of elite manhood, to make themselves humble soldiers, and to put themselves at God's disposal. Theirs was a sort of bourgeois sanctity, based on renunciation of privilege rather than social marginalization.

While the Zouaves were intensely dedicated to the Virgin, Mary did not

${ }^{116}$ Rudolph Bell and Cristina Mazzoni, The Voices of Gemma Galgani: The Life and Afterlife of a Modern Saint (Chicago, 2003); Harris, Lourdes; William Christian, Visionaries: The Spanish Republic and the Reign of Christ (Berkeley, 1996); Caffiero, "Dall'esplosione mistica," 257-59; David Blackbourn, Marpingen: Apparitions of the Virgin Mary in a Nineteenth-Century German Village (New York, 1993), 7-12.

${ }_{117}$ See, e.g., Poli, Souvenir du bataillon, 29-31. Poli and others seem to be responding to journalistic accusations that they were merely dilettante soldiers. While recruitment touched all classes of society, most Zouaves, especially those featured in the biographical literature, were from comfortably situated families. Zouaves themselves were fascinated by their own egalitarianism. See Guenel, La Dernière Guerre, esp. 42-44, 70, for statements about class blindness among the Zouaves; Guenel accepts these Zouave claims uncritically. Guérin and Rialan, significantly, came from relatively modest, nonnoble families.

${ }^{118}$ Bresciani, Le Zouave pontifical, 68-70. 
replace their own mothers. They were beloved sons of flesh-and-blood mothers, their families' hope for the future. An important part of what they sacrificed was the right to choose mothers for their own children and to become pères de famille in their own right. Mary became the channel by which mothers communicated with their grown sons, and she allowed mothers to participate in the distant triumph of their sons' martyrdom. Zouave sainthood was thus an encounter with God not only for elite boys but also for their motherswomen who realized, and then renounced, the ideals of bourgeois womanhood. The Zouave narrative suggested that the extraordinary grace of a visionary or a saint was not limited to those on the wretched and unhappy margins of society but was available to all those committed to sacrifice. Young men of good family, like poor women, could follow the path of virginity and martyrdom to holiness. ${ }^{119}$

Miraculous events in the Zouave narrative anticipated the wave of miracles and prophecies in France, described by Thomas Kselman, that accompanied the Franco-Prussian War and the fall of Rome. ${ }^{120}$ Unlike the mass pilgrimages to miracle sites of the early 1870 s, however, Zouave stories presented the experience of the miracle as intimate and profoundly personal, and they refused the consolation of prophecy. Joseph Guérin's tomb did attract thousands of pilgrims, but for the most part readers learned of Zouave sanctity in the intimate atmosphere created by Zouave biography - the devout reader contemplating the Zouave's own words and his family's correspondence. The miracles recounted were similarly personal and usually linked to the physical body of the martyred Zouave. Bodies preserved and bodies healed, relics taken from one body and held against another, were the building blocks of most zouave miracle tales.

The authors of Zouave stories were reluctant to be pinned down as to the manner of the ultimate miracle, God's intervention in favor of the church. Despite expressions of confidence that God would, indeed, save the papacy, the Zouave stories suggested that such salvation would not be a moment of miraculous change of fortune on the battlefield or change of heart on the part of Piedmontese politicians. Zouave narratives rejected the language of prophecy; they promised no specific moment of papal triumph as the culmination of Catholic suffering. The Zouaves' immediate goals - the preservation of undiminished papal territory and even, toward the end, the exercise of temporal

${ }^{119}$ Compare Caroline Ford, "Female Martyrdom and the Politics of Sainthood in Nineteenth-Century France: The Cult of Sainte Philomène," in Catholicism in Britain and France since 1789, ed. Frank Tallett and Nicholas Atkin (London, 1996), 115-34.

${ }^{120}$ Thomas A. Kselman, Miracles and Prophecies in Nineteenth-Century France (New Brunswick, NJ, 1983), chap. 5. See also Jonas, France and the Cult of the Sacred Heart. 
sovereignty - appeared as lost causes. Martyrs' deaths and the evidence of sanctity that they left behind wrought individual cures and individual conversions, and each miracle was an assurance that suffering did expiate human sin. Narrators of Zouave stories refused, however, to engage in the arithmetic of how such small, intimate miracles would add up to political, diplomatic, and military change. Devout Catholics would endure the discipline of grief without limit. Expiatory pain could not be banked and saved toward some specific goal; it had to be offered constantly and without measure.

\section{CONCLUSION}

Zouave stories are, in many ways, different from the plots of nineteenthcentury popular fiction or from the stories that historians tell about nineteenthcentury Frenchwomen and men. Accounts of Zouave suffering, martyrdom, and intercession are equally difficult to read if we assume a context either of a feminized church or of a bourgeois family life established by secular male achievement. ${ }^{121}$ The Zouave made himself the channel for papal devotion by abandoning ordinary social roles. Young laymen gave up promising futures and embraced celibacy, pain, and death. Women who called themselves "Zouaves in prayer" sacrificed their sons joyfully and signed pledges in blood. They undertook this violation of social norms deliberately, and they saw their actions as evidence of the importance of their cause and of the risks one ought to take in the face of the dangers of a world where the pope did not rule.

Zouave stories distributed male and female roles, but in ways that could be unexpected. Heroism drew on qualities that nineteenth-century men and women might both recognize in themselves: principally, a capacity for suffering and dedication. The miraculous saintliness of the Zouave pushed readers, both male and female, to identify also or instead with suffering mothers. The reader, like the Zouave's mother, was a devout Catholic asked to offer her church what she held most precious; in return, she received the assurance of the pope's blessing. Explaining the gender ambiguity of the Zouave story in terms of delicate, feminized men and fierce, masculinized women does little to clarify the emotional resonance of Zouave sacrifice among French Catholics. It makes far more sense to argue - as these Catholics would surely have done- that religious faith inflects gender identity. Women and men who fully identified with the passion of their suffering church would necessarily inhabit social

${ }^{121}$ This account of Zouave virtue differs significantly from recent work on bourgeois masculinity, including my own: Carol E. Harrison, The Bourgeois Citizen in NineteenthCentury France: Gender, Sociability, and the Uses of Emulation (Oxford, 1999); Robert A. Nye, Masculinity and Male Codes of Honor in Modern France (New York, 1993). 
identities different from those of people whose passions were primarily directed elsewhere.

The emotional resources that ultramontane Catholicism provided for the expression of individual grief and the mobilization of the faithful came packaged in narratives like those of the Zouaves. The Zouave was readers' physical and emotional tie to Pius IX and, beyond him, to God. The miracles of Zouave saints demonstrated the reality of this bond and reassured the devout that their suffering was redemptive. Although few families sent their sons to Rome, the Catholic response to their sacrifice, organized and channeled by the Zouave stories, ensured that the Roman drama remained at the forefront of French policy concerns, even when Napoleon III would have preferred that it recede from view. Large numbers of French Catholics followed the fate of the Zouaves and were thereby convinced that the Roman Question concerned God's order in the world and was not merely an issue for Italians. Catholic sentiment, nurtured in intimate and familial settings, thus had political effects that contributed to the foreign policy dilemmas of the end of the Second Empire. Repetition of the Zouave story, with the ritual evocation of physical and spiritual suffering that ran through all of its variations, generated a powerful vocabulary for Catholic men and women who hoped to produce militancy out of self-denial, individual suffering, and private anguish. 